\title{
肩関節衝突症候群の再手術例の検討
}

\author{
田中整形外科病院 \\ 金 崎 克 也・田 中 瑞 雄

\section{Review of Reoperated Shoulders with Impingement} \\ by

\section{Katsuya Kanesaki and Mizuo Tanaka} \\ Tanaka Orthopedic Hospital
}

\begin{abstract}
It seems that anterior acromioplasty described by Neer in 1972 has been accepted widely as a successful procedure for impingement syndromes in the shoulder especially in older individuals. We have also met with excellent results following the Neer procedure.

In this report we reviewed four shoulders of three patients which were reoperated on in accordance with Neer in our hospital more than six months before because of persistent impingement in spite of the previous one or two operations in other institutions and found following three points deserving of emphasis through the findings at the operation, reconfirming the effectiveness of the Neer procedure.

1) To minimize a damage to the function of the deltoid muscle, it is imperative that it should be detached or devided through an optimum approach and restored anatomically.

2) It should be recognized that the degenerated $\mathrm{AC}$ joint is an important contributor to rotator cuff impingement and that the anterior acromioplasty of Neer is not limited only to the coracoacromial arch when the AC joint is degenerated.

3) In younger patients with impingement, it is important to realize that it may be a continuum of some type of instabilities and that the impingement should never be surgically repaired without repairing the primary instability, if present.
\end{abstract}

\section{は じめに}

肩関節の chronic impingement syndrome はわれわ れの腱板断裂に対する考え方に変革をもたらした画期 的な概念である ${ }^{5) 7}$. それに対する手術法としての anterior acromioplastyも広く受け入れられつつあるよう であるが，本邦ではいまだなお旧態依然の手術法も行 われているようである。

われわれは，他の施設で手術を受けたが, 症状が改 善されず，再手術を余儀なくされ，術後半年以上経過 した 3 症例 4 肩を経験した. 基本的には Neer 法にて処 置したが，これら 4 肩の手術時所見および手術内容を 検討し, impingemet syndrome の手術に際しての留意 すべき知見を得た。
症

例

3 症例 4 肩のうち，2 肩は再手術，他の 2 肩は再々 手術例であった（表 1 ）。

術前 4 肩とも, 労作時痛は当然のことながら, 夜間 痛による不眠を強く訴えていた，客観的には，可動域 制限が著明に認められ, とくに外転域が全例とも 90 度 以下であった。

症例 1 , 59 才男: 前回手術では, 腱板縫合のみを Deltopectoral approach に行ったものと思われるが, 三角筋前 3 分の 1 部の萎縮を結果しただけで腱板の広 汎断裂も残存していた症例である（表 1 ）.

今回手術では，前回手術の縦切開部を肩鎖関節上に 延長した approach にて, anterior acromioplasty 加え，変性した肩鎖関節については resection 
表 1 手術時所見および手術回数

\begin{tabular}{|c|c|c|c|c|c|c|c|c|}
\hline & 手術回数 & 三角 筋 & acro & iopl & asty & $\begin{array}{l}\text { 肩鎖関節 } \\
\text { 骨棘形成 }\end{array}$ & 腱板 & その 他 \\
\hline $\begin{array}{l}\text { 症例 } \\
59 才\end{array}$ & 1 & 萎縮 痖痕化 & 未 & 施 & 行 & H & 広範断裂 & \\
\hline $\begin{array}{l}\text { 症例 } \\
65 \text { 才男 }\end{array}$ & 2 & 同上 & 不 & 充 & 分 & H & 痗痕にて連絡 & \\
\hline $\begin{array}{l}\text { 症例 } 3 \text { 右 } \\
45 \text { 才女 }\end{array}$ & 2 & $\begin{array}{l}\text { 絹系による } \\
\text { 肉芽形成 }\end{array}$ & & 充 & & H & $\begin{array}{l}\text { 表 層 の } \\
\text { erosion }\end{array}$ & \\
\hline 左 & 1 & $\begin{array}{c}\text { 萎 縮 } \\
\text { 一部痗痕化 }\end{array}$ & 不 & 充 & 分 & + & 上 & instability \\
\hline
\end{tabular}

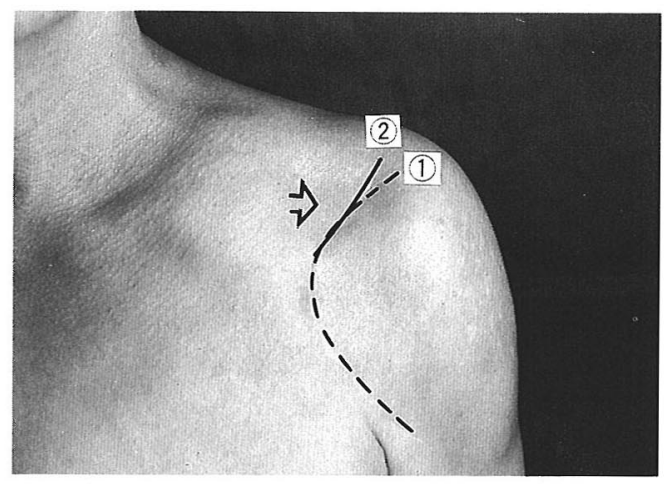

図 1 症例 265 才男 左肩

(1)点線前回の手術瘫痕 (2)実線今回の手術癜痕 矢印 : 三角筋萎縮

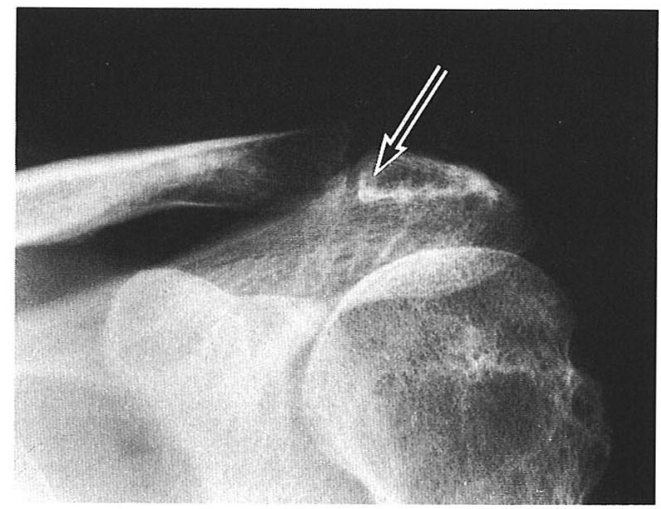

図 2 症例 265 才男 左肩 肩鎖関節の骨棘形成

arthroplasty ${ }^{2)}$, 上腕二頭筋長頭筋腱の部分断裂には腱 固定を行い，広沈な腱板断裂には fascia lata を用いた
縫合術を施行した。術後経過は良好で夜間痛は消失し， 可動域も改善してはいるが，労作後痛を訴えている. これには三角筋，とくに前 3 分の 1 部の萎縮も関与し ているものと考えられる。

症例 2 , 65才男: 再々手術例である。長大な Deltopectoral approach (図 1) にて手術が行われて いたため，三角筋の著明な萎縮と癜痕化を認め， acromioplasty は行われてはいたが不充分であった症例 である (表 1 )。

肩鎖関節に著明に骨棘が認められ(図 2 )，肩峰下に 残存していた骨棘の充分な切除 ${ }^{3)}$ ともに, resection arthroplasty ${ }^{2)}$ を施行した。縫合されたと思われる腱板 は, 強く肩峰に癒着しておう，剥離すると，薄い痒痕 組織で結節部と連絡しているのみであったので，補強 と癒着防止の目的にて人工硬膜を使用し縫縮術を行っ た。三角筋前 3 分の 1 部は，廄痕部を切除し鎖骨およ び前肩峰部に再縫合した。

術後, 易疲労性が残存し, 完全挙上は不能であるが, 患者は満足している。

症例 3，45 才女：交通事故を契機に発症した両肩手 術例である。症例 1,2 と異なり, 若年者症例 ${ }^{1)}$ として 考えるべき症例である。

(1)右肩：再々手術例である。どういう意図でなされ たのか理解に苦しむが, 肩峰外縁部より外側に向う $4 \mathrm{~cm}$ の皮膚切開にて手術がなされていた（図 3).Neerの approach $^{5)}$ にて展開すると不充分な acromioplasty が なされており, approach からみて当然であるが, 鳥口 肩峰勒帯が手つかずのまま残存していた。腱板には大 結節部で erosionが認められた（表 1). anterior acromioplasty とともに外旋制限改善のため, 烏口上腕 


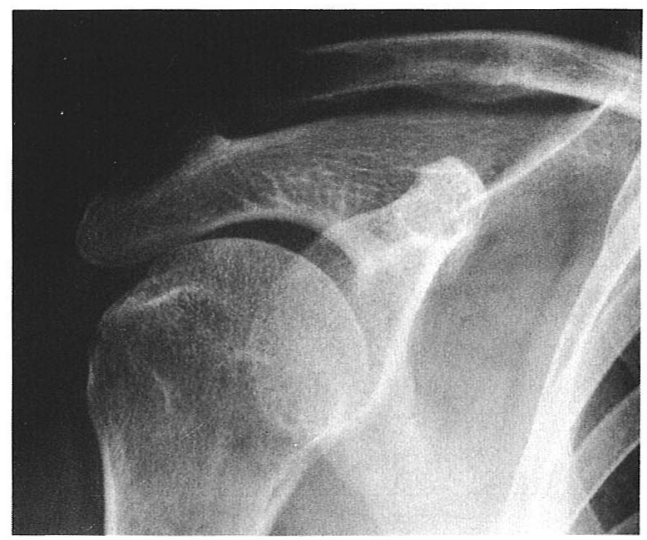

右局

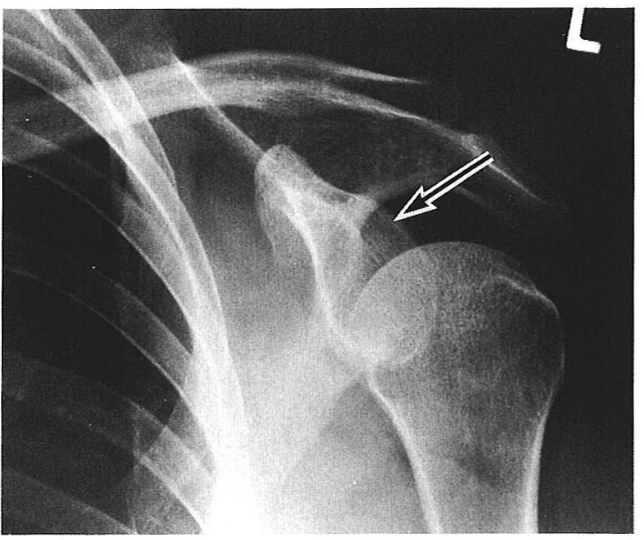

左肩

図 3 症例 345 才 女 術前の負荷 $X-p$

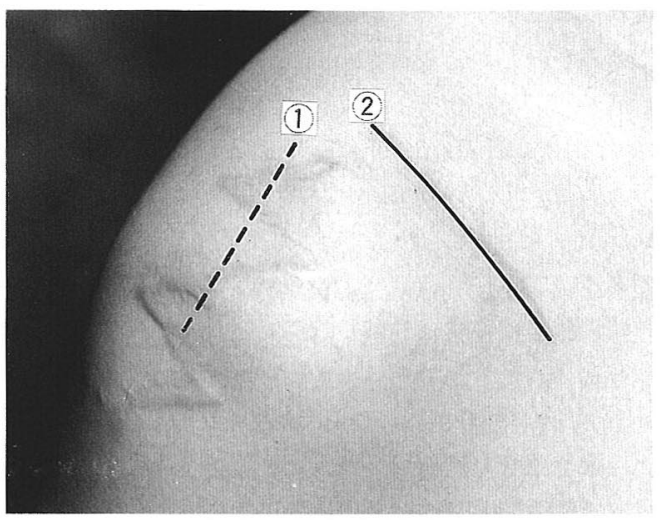

図 4 症例 3 45 女 右肩

(1)点線 前回の手術痏痕

(今回 Z-plasty 施行)

(1)実線 今回の手術瘏痕

勒帯の切離も加えた。

術前, 肩峰上に強い圧痛が認められたが, 三角筋を 縫着するのに用いられた太い絧系数本が見いだされ， これを切除した。またケロイド化していた手術痒痕の Z-plastyも施行した.

(2)左肩：術前に下方動摇性を認めた症例である（図 $4)$.

鎖骨前緑より肩峰前外縁部に至る approach が用い られており，三角筋の縫合不全による前 3 分の 1 部の 著明な萎縮と痏痕化が認められた。右肩同様, Neer の approach を用いて手術を施行した. 術前に認められた instability は, rotator interval の弛緩によるもので,
縫縮術を施行した。肩鎖関節下面に骨棘が認められ， 肩峰下に残存していた骨棘とともに切除した，右肩同 様, 外旋制限に対して鳥口上腕勒带の切離も施行した (表 1).

術後, 両肩とも夜間痛は消失し，可動域も改善され てはいるが, とくに左肩の易疲労性が遺っている.

\section{考察}

4 肩に認められた所見（表 1) より，まず三角筋の 処置の問題が浮び上る. Neer ${ }^{6}$ が指摘している通り, 三角筋の起始部は解剖学的に修復されないと瘢痕菱縮 を結果し, 術後の愁訴, すなわち労作後の疼痛あるい は, 易疲労性につながると考えられる。つまり, approach は三角筋への侵襲を最小とし, 解剖学的修復を前提と するものでなければならない. とくに，起始部の肩峰 および鎖骨よりの切離は fibrous な組織を三角筋に残し て行うべきである，筋腹内に切離が入ると縫合が困難 なのは明らかである。

anterior acromioplasty は, coracoacromialarch $に$ ついては言うにおよばず, Watson ${ }^{8)}$ の報告にあるよう に, 肩鎖関節の impingement への関与も考慮すべきで ある. acromioplasty 抢よび肩鎖関節の処置が不充分で あれば, 症例 1 のごとく, 何如なる腱板縫合も無意味 であり, 症例 3 で認められた erosive lesion が示すよ うにさらなる腱板の変性を結果することにつながる。 Neer の述べるがごとく腱板の変性は impingement に 続く二次的なものであることを理解すべきである。

症例 3 の左肩は, Jobe ${ }^{4)}$ の報告にあるように, instabil- 
ity を前提とした impingement syndromeであったと 考えるべき症例である，若年者の impingement syndrome では, Neer の impingement sign のみならず, 肩関節の stability についても精査すべきである. instability があれば,これに対する修復を行わなければ, 症 状改善が望めないことは自明であり，その原因につい ての術前把握は手術法を決定するものと言える。

Neer の提唱する approach は, 一見術野が狭く感じ られるが，肩鎖関節は言うにおよばず，上腕二頭筋長 頭筋腱の処置も上腕骨を回旋させることで充分可能で ある.またこの approach の利点は, 三角筋への侵襲が 少なくその機能回復が良好であることもあげられ，わ れわれも多数経験しているところである.

\section{結語}

3 症例 4 肩の再手術例の経験から, impingement syndrome の手術に関して以下の知見を得た。

1. 適切な approach に基づき三角筋の侵襲は最小

とし，解剖学的修復を行うべきである。

2. anterior acromioplasty は, impingement $の$ 根 源である coracoacromial archにとどまらず，変性し た肩鎖関節に対する処置も含めて行うべきである.

3. 若年者では, instability の有無に留意し，あれ ばこれに対する処置を行うべきである。

4. これらの処置は,われわれが使用している Neer の approach で充分遂行できる.

\section{参 考 文 献}

1) Bigliani, L. u., DAlessandro, D. F., Duralde, X. A., and Mcllveen, S. J.: Acromioplasty for Suba- cromial Impingement in Patient Younger Than 40 Years of Age. Clin. Ortho. 246: 117-123, 1989.

2) Daluga, D. J. and Dobozi, W.: The Influence of Distal Clavicle Resection and Rotator Cuff Repair on the Effectiveness of Anterior-acromioplasty. Clin. Orthop. 246 : 111-116, 1989.

3) Hawkins, R. J., Brock, R. M., Abrams, J.S., and Hobeika, P.: Acromioplasty for Impingement with an Intact Rotator Cuff. J Bone and Joint Surg. (Br) 70-B : 795-797, 1988.

4) Jobe, F. W.: Impingement Problems in the Ath lete. A. A. O. S. : Instructional Course Lecture. XXX VIII, 205-209, 1989.

5) Neer, C. S., II : Anterior Acromioplasty for the Impingement Syndrome in the Shoulder. A Preliminary Report. J. Bone and Joint Surg. 54-A : 41-50, 1972.

6) Neer, C. S., II, and Marberry, T. A. : On the Disadvantages of Radical Acromionectomy. J. Bone and Joint Surg. 63-A : 416-419, 1981.

7) Neer, C. S., II. : Impingement Lesion. Clin. Orthop. 173: 70-77, 1983.

8) Watson, M: Rotator Cuff Function in the Impingement Syndrome. J. Bone and Joint Surg. 71 -B : 361-366, 1989 .

質 問 長崎大学 伊藤 信之 impingement と instability が同時に生じた理由をお しえて下さい.

\section{解 答田中整形外科病院 金崎 克也}

Jobe が論文中に述べている様に, anterior への instability が存在していれば acromion と大結路との間に impingement が起こることは明白です。 